\title{
Systematic Review of Studies Using Conjoint Analysis Techniques to Investigate Patients' Preferences Regarding Osteoarthritis Treatment
}

This article was published in the following Dove Press journal: Patient Preference and Adherence

\author{
Basem Al-Omari (D) \\ Peter McMeekin ${ }^{2}$ \\ Angela Bate ${ }^{2}$ \\ 'College of Medicine and Health \\ Sciences, Khalifa University, Abu Dhabi, \\ United Arab Emirates; ${ }^{2}$ School of Health \\ and Life Science, University of
} Northumbria, Newcastle-Upon-Tyne, UK

Correspondence: Basem Al-Omari College of Medicine and Health Sciences, Khalifa University, PO Box 127788, Abu

Dhabi, United Arab Emirates

Tel +97I 28109807

Email basem.alomari@ku.ac.ae
Background: The use of conjoint analysis (CA) to elicit patients' preferences for osteoarthritis (OA) treatment has the potential to contribute to tailoring treatments and enhancing patients' compliance and adherence. This review's main aim was to identify and summarise the evidence that used conjoint analysis techniques to quantify patient preferences for OA treatments.

Methods: A comprehensive search strategy was conducted using electronic databases and hand reference checks. Databases were searched from their inception until 10th June 2019. All OA and CA related terms were used to conduct the search. The authors reviewed the papers and used the International Society of Pharmacoeconomics and Outcomes Research (ISPOR) checklist to assess the quality of the included studies.

Results: The search identified 534 records. Sixteen records were selected for full-text review and quality assessment and all were included in the narrative data synthesis. All included studies suggested that the severity of symptoms influenced the patients' preference for OA treatment. All included studies recognised CA as a useful method to investigate patients' preferences concerning OA treatment.

Conclusion: Patients preference for OA treatment is driven by the severity of patients' symptoms and the desire to avoid treatment side effects and CA is a useful tool to investigate patients' preferences for OA treatment.

Keywords: patient preferences, osteoarthritis, conjoint analysis

\section{Background}

Osteoarthritis (OA) is the most common form of arthritis. ${ }^{1}$ It is a long-term chronic disabling degenerative joint disease that causes pain and limitation of movement. ${ }^{2,3}$ Pain associated with OA substantially reduces the patient's mobility and quality of life. ${ }^{4}$ Treatments primarily target joint pain to maintain and improve joint mobility. ${ }^{5}$ Options include surgery, pharmacological and non-pharmacological treatments. ${ }^{6,7}$ However, alternative treatments differ in terms of the risks and benefits offered. Preferences for alternative treatments vary across individuals and depend on how they value the benefits relative to the associated risks. ${ }^{8,9}$

It has increasingly become the goal of healthcare systems to promote patient involvement, ${ }^{10}$ especially that the discordant patient and healthcare provider preferences for different attributes of healthcare interventions are common. ${ }^{11}$ In the United Kingdom (UK), the Health and Social Care Act 2012 made clear the duties of the national health service (NHS) to involve patients in the decisions about their 
treatment. $^{12}$ The use of stated preference techniques to elicit and understand patients' preferences and values for health services and treatments to then inform treatment decisions is an accepted method of promoting patientcentred care ${ }^{13-15}$ and its use has grown dramatically. ${ }^{16-18}$ Specifically, identifying patients' preferences for OA treatment offers a potential method for tailoring treatments, enhancing compliance, and improving patients' satisfaction. ${ }^{19}$

One of the commonly used stated preference methods is conjoint analysis $(\mathrm{CA})^{20,21}$ which is a popular analytical technique for eliciting preferences. $^{22}$ The idea behind $\mathrm{CA}$ is that it closely resembles the decisions that individuals make daily when choosing between multi-attribute alternatives. ${ }^{23}$ The popularity of CA in health care is growing and it has gained increasing attention in health services research. ${ }^{24,25}$ It is used as a method to measure patient preferences for health care and medicine, and as a means to identify and evaluate the relative importance of aspects of health outcomes and healthcare services. ${ }^{26,27} \mathrm{CA}$ methods and particularly discrete-choice experiments (DCEs) have become the most frequently applied approach in health care in recent years. ${ }^{28} \mathrm{~A}$ review of published studies using DCEs to quantify preferences in healthcare reported that their use increased from fewer than 20 per year on average in the 1990 s to over 60 published per year between January 2013 and December 2017. ${ }^{29}$ Whilst DCEs are not the only conjoint analysis method, they make up the majority of published stated preference studies in healthcare. ${ }^{29}$ Other CA techniques include traditional choice based conjoint (CBC), best-worst scaling (BWS), adaptive conjoint analysis (ACA) and adaptive choice-based conjoint (ACBC). All techniques require participants to compare and make trade-offs between a set of attributes and levels that define the health service or treatment under evaluation, and the trade-offs that participants make between these. ${ }^{30}$

Alongside the increasing use of CA techniques, increased attention has been paid to their methodological quality. In 2011 and prior to the Health and Social Care Act of (2012), the International Society of Pharmacoeconomics and Outcomes Research (ISPOR) published a checklist for good research practices for CA studies, highlighting the items to be considered for best practice for CA applications in healthcare studies. ${ }^{26}$

This systematic review aims to identify, summarise, and assess the methodological quality of the evidence that used CA techniques to quantify patient preferences for OA treatments and identify common approaches and methods employed and attributes considered important in eliciting patients' preferences regarding OA treatment.

\section{Methods}

\section{Search Strategy}

A comprehensive search strategy was developed by the lead author. The Cochrane Library, PubMed (MEDLINE), CINHAL, EMBASE, and web of science were electronically searched from their inception until 10th June 2019. Medical Subject Headings (MeSH) and search terms were used to interrogate the databases. OA and CA related terms were used to conduct the search. No restrictions on publication language were used in the search strategy (appendix 1 shows an example of a MEDLINE search). In addition, electronic searching of Google, hand searching through an examination of the reference list of the published articles and contact with experts were also used to identify additional publications.

Three authors reviewed the titles and abstracts and evaluated all records against the inclusion/exclusion criteria.

\section{Inclusion Criteria}

Studies included in the review fulfilled the following criteria: 1) used any conjoint analysis methodology to elicit patient preferences including Conjoint Value Analysis (CVA), Choice-Based Conjoint (CBC), Discrete Choice Experiments (DCE), Best-Worst Scale (BWS), Adaptive Conjoint Analysis (ACA) and Adaptive Choice-Based Conjoint (ACBC); 2) focussed on patients diagnosed with OA irrespective of their age, gender, illness severity or joint of the body affected; 3) considered any form of OA intervention treatment.

\section{Exclusion Criteria}

Studies were excluded from the review if 1) participants were clinicians or healthcare workers (ie, not patients); 2) the focus was on the economic evaluation or willingness to pay (WTP) of a service or intervention; 3) the evaluation was restricted to quality rather than effectiveness or patient preference; 4) the focus was on the priority of treatment allocation, such as prioritising patients on the waiting list.

\section{Quality Assessment and Data Extraction}

The included papers were quality assessed and the data were extracted by the three authors. The ISPOR checklist 
for $\mathrm{CA}^{26}$ was adopted to review and assess the methodological quality of studies included in this review. In the absence of a validated tool for quality assessment of CA studies, we considered the use of ISPOR checklist to guide this process. The checklist contains 10 main questions, each has 3 sub-questions, which adds up to 30 items in total. ${ }^{26}$ Studies were assigned a score of " 1 " for each item of the ISPOR checklist if they were considered to meet at least one aspect of this item and " 0 " if not. A total score for each study was calculated by summing the item scores. The maximum possible final score was 30 .

A data extraction form was developed by two authors. Key data elements included: study aims, population characteristics (country, number, age, and gender), sampling method, response rate, CA method, inclusion criteria, treatment, attributes, levels, and scenarios, statistical analysis, main results, and authors' conclusion.

The included papers were independently assessed and scored by at least two of the three authors. Where there was a conflict of interest or potential reviewer bias, the reviewer in question was not involved in the assessment of scoring or the data extraction. Disagreements were resolved by discussion and consensus between all authors. A narrative data synthesis approach was used to analyse and report the results from the studies reviewed.

\section{Results}

\section{Studies Identified}

The search identified 534 records. Three hundred and sixteen records remained after removing duplicates. Based on the titles/abstracts review, a total of 297 records were deemed irrelevant and excluded as they did not meet one or more of the inclusion criteria. A further three records were excluded as they were published as conferences proceeding abstracts and the full reports were not published and not available from the authors. The remaining sixteen records were selected for full-text review and quality assessment. The PRISMA flowchart illustrating this process (see Figure 1).

\section{Quality Assessment}

Sixteen studies were included in the review. The quality assessment scores of studies ranged between 19/30 and 29/ 30. This indicates that these studies fulfil at least 19 of the 30 best practice criteria in the ISPOR checklist. Across the 16 studies, there was low variation in total and individual item scores. Furthermore, the checklist did not provide emphasis to the themes that may have not been considered in the studies, which resulted in a high level of subjectivity in relation to the judgments made regarding the individual and total scores. Therefore, we are unable to make judgments on the quality of the studies or discriminate based these scores.

\section{Study Population, Sample Size and Recruitment}

All the included studies expressed a clearly defined research aim and conducted original research to examine patients' preferences comparing OA treatments (exercise, drug, or surgery), and presented testable hypotheses (see Table 1).

Fifteen studies were conducted in a single country site - one in Australia, five in the UK, and nine in the United States of America (USA). One study was conducted across multiple countries - Australia, Canada, the UK, and the USA. Sample sizes for the studies ranged from 11 in the pilot study ${ }^{31}$ to 3895 the multi-site study. ${ }^{32}$ Justifications for the sample sizes were based on the study type (eg, whether it was a pilot study or part of a larger trial) and the sampling strategies employed. Most studies recruited patient participants from clinical lists directly using letters, telephone interviews or face-to-face methods. Four studies sampled members of the general population via emails through market research databases to recruit participants who self-identified as living with OA. One study recruited participants from both clinical lists - the patient sample; and a random public sample (identified through random-digit telephone dialling). ${ }^{23}$ One study recruited participants from a clinical trial as part of the evaluation $^{33}$ (see Table 2).

All studies included participants with OA, mean age 55 years or more, and reported higher numbers of females to males. One study included a public sample of people age 20 and over. ${ }^{23}$ One study did not report the gender of their population. ${ }^{19}$ The response rates (RR) reported varying from $7.6 \%^{32}$ to $100 \%{ }^{9,31,34,35}$ in the included studies, population and sampling features are presented in Table 2. The methods of data collection used in the studies also vary, reporting mostly either computer-based questionnaire, $, 31,34-40$ or online webbased questionnaires ${ }^{32,40,41}$ (see Table 2).

\section{Conjoint Analysis Method}

A range of $\mathrm{CA}$ methods was used in the included studies. One study used Conjoint Value Analysis (CVA), three studies used Choice-Based Conjoint (CBC), three studies used 


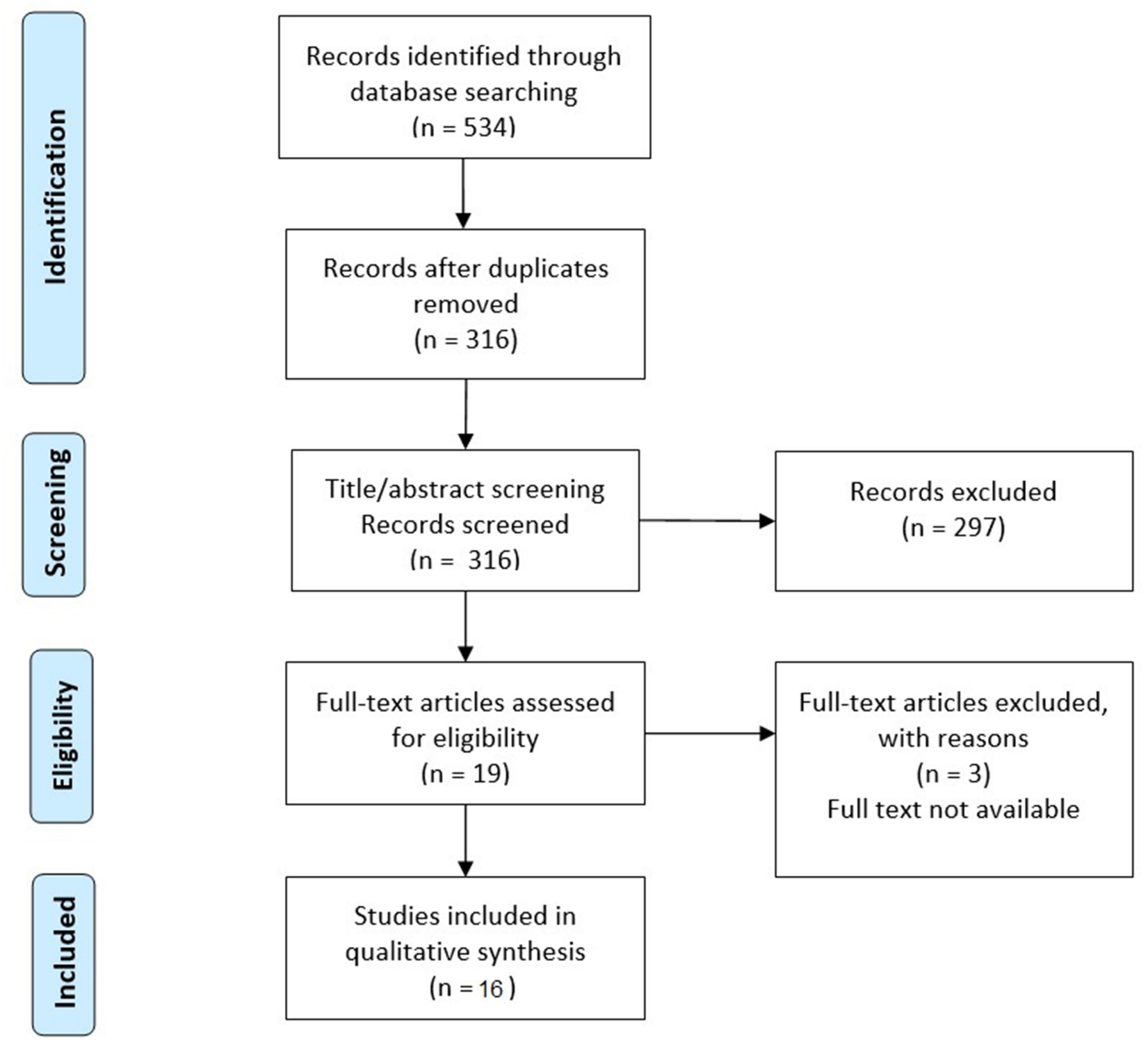

From: Moher D, Liberati A, Tetzlaff J, Altman DG, The PRISMA Group (2009). Preferred Reporting Items for Systematic Reviews and Meta-Analyses: The PRISMA Statement. Plols Med 6(7): e1000097. doi:10.1371/iournal.pmed1000097

Figure I The PRISMA flowchart.

Notes: Adapted from Moher D, Liberati A, Tetzlaff J, Altman DG, The PRISMA Group (2009). Preferred Reporting Items for Systematic Reviews and Meta-Analyses: The PRISMA Statement. PLoS Med. 2009;6(7):el000097. (c) 2009 Moher et al. Creative Commons. ${ }^{54}$

Discrete Choice Experiments (DCE), three studies used Adaptive Choice-Based Conjoint (ACBC), and six studies used Adaptive Conjoint Analysis (ACA) (see Table 3). The number of attributes and levels identified in the studies ranged from 4 attributes with 12 levels $^{35}$ to 9 attributes with 29 levels $^{41}$ (see Table 3). The attributes tended to define the features of the OA symptoms, OA treatment such as the benefits and the risks, and cost of treatment (for all attributes and levels of the included studies see appendix 2).

\section{Statistical Analysis}

In all types of CA, regression analysis techniques are generally used to study the patient's preference. The choice of regression analysis type in CA depends on the type of the main outcome under study (eg, binary outcome, continuous outcome, etc.). More recent studies have adopted Hierarchical Bayesian (HB) models to investigate participants' preferences at both the group "average" level as well as at the individual level ${ }^{31,35,41}$ (see Table 3). 
Table I Type of OA Treatment, Aims, and Findings for All Reviewed Studies

\begin{tabular}{|c|c|c|c|}
\hline Study & OA Treatment & Aims & Findings \\
\hline Al-Omari, $(2017)^{31}$ & Pharmaceutical treatment & $\begin{array}{l}\text { The aim of the present study was to } \\
\text { evaluate the use of } A C B C \text { in eliciting } \\
\text { treatment preferences by determining the } \\
\text { relative importance of } 8 \text { attributes in } \\
\text { selecting pharmaceutical treatment of OA. }\end{array}$ & $\begin{array}{l}\text { ACBC is a potentially valid method of } \\
\text { evaluating patients' preferences for } \\
\text { pharmaceutical treatment of OA. The } \\
\text { current findings indicate that OA patients } \\
\text { are most concerned with the avoidance of } \\
\text { adverse events and that there is a threshold } \\
\text { above which expected benefit has little } \\
\text { impact on patients' medication preferences. }\end{array}$ \\
\hline $\begin{array}{l}\text { Al-Omari et al } \\
(2015)^{34}\end{array}$ & Pharmaceutical treatment & $\begin{array}{l}\text { The aim of this study was to examine the } \\
\text { feasibility of } A C B C A \text { in patients with } O A \text {. }\end{array}$ & $\begin{array}{l}\text { Adequate face and measurement validity of } \\
\text { an ACBCA task can be achieved through } \\
\text { a developmental process taking account of } \\
\text { participants' requirements. The involvement } \\
\text { of participants during the design phase of the } \\
\text { task enabled the research team to construct } \\
\text { an ACBCA task that resulted in participants } \\
\text { reporting that the task helped them to } \\
\text { identify their medication preferences for the } \\
\text { treatment of osteoarthritis. }\end{array}$ \\
\hline $\begin{array}{l}\text { Al-Omari et al } \\
(2017)^{9}\end{array}$ & Pharmaceutical treatment & $\begin{array}{l}\text { The aim of the current study was to } \\
\text { investigate the potential of } A C B C \text { as an } \\
\text { approach to supporting shared decision- } \\
\text { making with individual patients in clinical } \\
\text { practice. }\end{array}$ & $\begin{array}{l}\text { Individual patients have preferences that are } \\
\text { likely to lead to different medication choices. } \\
\text { ACBC has the potential to identify individual } \\
\text { preferences as a practical basis for concordant } \\
\text { prescribing for osteoarthritis in clinical practice. }\end{array}$ \\
\hline $\begin{array}{l}\text { Byrne et al } \\
(2006)^{23}\end{array}$ & Total Knee Replacement & $\begin{array}{l}\text { Exploring ethnic differences in preferences } \\
\text { for surgery in the context of knee OA and } \\
\text { Total Knee Replacement (TKR). }\end{array}$ & $\begin{array}{l}\text { Differences in knee replacement rates } \\
\text { among ethnic groups could be partly due to } \\
\text { differences in preferences for surgery. } \\
\text { Conjoint analysis is a feasible methodology } \\
\text { for collecting preferences in health research } \\
\text { and it contribute to the decision-making } \\
\text { process of health care practitioners. }\end{array}$ \\
\hline $\begin{array}{l}\text { Chang et al } \\
(2005)^{32}\end{array}$ & NSAIDs & $\begin{array}{l}\text { To describe the health state preferences of } \\
\text { patients with OA according to their level of } \\
\text { pain and disability and according to the } \\
\text { extent of gastrointestinal side effects from } \\
\text { NSAIDs. }\end{array}$ & $\begin{array}{l}\text { Disease severity appeared to have a greater } \\
\text { effect on ratings than did side effect severity, } \\
\text { but we cannot conclude that patients value } \\
\text { disease severity more than side effect } \\
\text { severity because these were not compared } \\
\text { directly on the same scale. }\end{array}$ \\
\hline $\begin{array}{l}\text { Fraenkel et al } \\
(2004 \mathrm{~A})^{37}\end{array}$ & $\begin{array}{l}\text { Oral NSAIDs, (COX-2) } \\
\text { inhibitors, opioid, } \\
\text { Glucosamine and/or } \\
\text { Chondroitin sulfate, Capsaicin. }\end{array}$ & $\begin{array}{l}\text { To examine whether the current widespread } \\
\text { use of anti-inflammatory drugs may reflect } \\
\text { a lack of informed choice among older } \\
\text { patients with knee osteoarthritis (OA). }\end{array}$ & $\begin{array}{l}\text { When evaluating multiple alternatives, many } \\
\text { older patients with knee osteoarthritis are } \\
\text { willing to forgo treatment effectiveness for } \\
\text { a lower risk of adverse effects. }\end{array}$ \\
\hline $\begin{array}{l}\text { Fraenkel et al } \\
(2004 \mathrm{~B})^{38}\end{array}$ & $\begin{array}{l}\text { Oral NSAIDs, (COX-2) } \\
\text { inhibitors, opioid, } \\
\text { Glucosamine and/or } \\
\text { Chondroitin sulfate, } \\
\text { Capsaicin. }\end{array}$ & $\begin{array}{l}\text { Examine older patients' treatment } \\
\text { preferences for knee OA, determine the } \\
\text { influence of specific medication } \\
\text { characteristics on patients' choices, and } \\
\text { examine whether patients' preferences are } \\
\text { consistent with current practice. }\end{array}$ & $\begin{array}{l}\text { Patients prefer the less effective but safer } \\
\text { choice of treatment. The widespread use of } \\
\text { anti-inflammatory drugs may, in part, reflect } \\
\text { lack of informed choice among older } \\
\text { patients with OA. Health care providers } \\
\text { should encourage patient participation in } \\
\text { decision-making to ensure informed choice } \\
\text { among older adults with arthritis. }\end{array}$ \\
\hline
\end{tabular}

(Continued) 
Table I (Continued).

\begin{tabular}{|c|c|c|c|}
\hline Study & OA Treatment & Aims & Findings \\
\hline $\begin{array}{l}\text { Fraenkel et al } \\
(2004 C)^{36}\end{array}$ & $\begin{array}{l}\text { Oral NSAIDs, (COX-2) } \\
\text { inhibitors, opioid, } \\
\text { Glucosamine and/or } \\
\text { Chondroitin sulfate, } \\
\text { Capsaicin. }\end{array}$ & $\begin{array}{l}\text { To test whether the widespread use of } \\
\text { cyclooxygenase-2 (COX-2) inhibitors may } \\
\text { be mediated in part by a perception that } \\
\text { COX-2 inhibitors eliminate the risk of } \\
\text { serious gastrointestinal (GI) events in } \\
\text { contrast to merely reduce their risk. }\end{array}$ & $\begin{array}{l}\text { OA patients' preferences for COX-2 } \\
\text { inhibitors over NSAID are strongly } \\
\text { influenced by the appeal of zero risk of side } \\
\text { effects. The willingness shown by older } \\
\text { adults to pay for COX-2 inhibitors may } \\
\text { reflect a misperception of the risk of toxicity } \\
\text { associated with these medications. }\end{array}$ \\
\hline $\begin{array}{l}\text { Fraenkel and Fried, } \\
(2008)^{42}\end{array}$ & $\begin{array}{l}\text { Acetaminophen Capsaicin. } \\
\text { Oral NSAIDs. } \\
\text { Intra-articular (IA) Injections. } \\
\text { Exercise. }\end{array}$ & $\begin{array}{l}\text { To examine patient preferences for exercise } \\
\text { in comparison to other osteoarthritis } \\
\text { treatment options. }\end{array}$ & $\begin{array}{l}\text { Patients preferred exercise over other } \\
\text { treatment options, whether intra-articular } \\
\text { injections or NSAIDs were } 20 \% \text { or } 50 \% \\
\text { more effective at decreasing symptoms } \\
\text { compared to other options. The relative } \\
\text { importance assigned to treatment benefits } \\
\text { and risks were } 29 \% \text { and } 41 \% \text { respectively. }\end{array}$ \\
\hline $\begin{array}{l}\text { Fraenkel et al } \\
(20 \mid 4)^{35}\end{array}$ & $\begin{array}{l}\text { Disease modifying drugs for } \\
\text { osteoarthritis (DMOADs) }\end{array}$ & $\begin{array}{l}\text { The objectives of this study were to I) } \\
\text { quantify patient preferences for hypothetical } \\
\text { DMOADs over a specified range of risks, } \\
\text { benefits and costs using conjoint analysis } \\
\text { and } 2 \text { ) determine the added value of latent } \\
\text { class segmentation analysis in understanding } \\
\text { the breadth of patients' perspectives. }\end{array}$ & $\begin{array}{l}\text { Many patients might be willing to accept } \\
\text { some degree of risk to prevent worsening } \\
\text { knee OA. }\end{array}$ \\
\hline $\begin{array}{l}\text { Harris et al } \\
(2018)^{44}\end{array}$ & $\begin{array}{l}\text { Arthroplasty versus } \\
\text { arthrodesis }\end{array}$ & $\begin{array}{l}\text { To compare preferences for arthroplasty } \\
\text { versus arthrodesis in patients with proximal } \\
\text { interphalangeal joint osteoarthritis. }\end{array}$ & $\begin{array}{l}\text { Joint stiffness and grip strength emerged as } \\
\text { the leading patient preference drivers, need } \\
\text { for future surgery and cost were moderate } \\
\text { influencing factors, and recovery time } \\
\text { proved to be least important. Offering } \\
\text { arthroplasty as the first-line surgical option } \\
\text { is a highly patient-centered approach. }\end{array}$ \\
\hline $\begin{array}{l}\text { Hauber et al } \\
(2013)^{39}\end{array}$ & $\begin{array}{l}\text { NSAIDs and selective COX- } \\
2 \text { inhibitors. }\end{array}$ & $\begin{array}{l}\text { To estimate OA patients' risk tolerance for } \\
\text { serious adverse events including bleeding } \\
\text { ulcer, MI, and stroke. }\end{array}$ & $\begin{array}{l}\text { Patients generally attached greater } \\
\text { importance to eliminating the risks of } \\
\text { adverse events than in reducing pain. }\end{array}$ \\
\hline Laba et al $(2013)^{33}$ & Pharmaceutical & $\begin{array}{l}\text { To estimate the relative influence } \\
\text { of medication-related factors and respondent } \\
\text { characteristics on decisions to continue } \\
\text { medications among people with symptomatic } \\
\text { OA. }\end{array}$ & $\begin{array}{l}\text { Medication risks and cost were important } \\
\text { and ought to be borne into considerations in } \\
\text { interpreting clinical trial evidence for } \\
\text { practice. }\end{array}$ \\
\hline $\begin{array}{l}\text { Moorman et al } \\
(2017)^{41}\end{array}$ & Surgical & $\begin{array}{l}\text { To obtain patient-preference evidence to } \\
\text { inform regulatory approval decisions by the } \\
\text { Food and Drug Administration (FDA) } \\
\text { Center for Devices and Radiological Health } \\
\text { during the benefit-risk assessment of } \\
\text { surgical interventions for knee OA. }\end{array}$ & $\begin{array}{l}\text { Stated patient preferences suggested that } \\
\text { patients with knee OA, particularly younger } \\
\text { patients with higher levels of pain and } \\
\text { functional restrictions, would prefer } \\
\text { a surgery that does not require bone cutting } \\
\text { or removal. }\end{array}$ \\
\hline
\end{tabular}

(Continued) 
Table I (Continued).

\begin{tabular}{|c|c|c|c|}
\hline Study & OA Treatment & Aims & Findings \\
\hline Pinto et al $(2019)^{40}$ & $\begin{array}{l}\text { Physical Activity preferences } \\
\text { (PA) }\end{array}$ & $\begin{array}{l}\text { To investigate individual preferences for PA } \\
\text { attributes in adults with chronic knee pain, } \\
\text { to identify clusters of individuals with similar } \\
\text { preferences, and to identify whether } \\
\text { individuals in these clusters differ by their } \\
\text { demographic and health characteristics. }\end{array}$ & $\begin{array}{l}\text { Patients with chronic knee pain have } \\
\text { preferences for PA that can be distinguished } \\
\text { effectively using ACA methods. Adults with } \\
\text { chronic knee pain, clustered by PA preferences, } \\
\text { share distinguishing characteristics. } \\
\text { Understanding preferences may help clinicians } \\
\text { and researchers to better tailor PA } \\
\text { interventions. }\end{array}$ \\
\hline $\begin{array}{l}\text { Ratcliffe et al } \\
(2004)^{43}\end{array}$ & NSAIDs & $\begin{array}{l}\text { To investigate the patient preferences for } \\
\text { attributes associated with the efficacy and } \\
\text { side-effects of treatment for osteoarthritis. }\end{array}$ & $\begin{array}{l}\text { Respondents were relatively more } \\
\text { concerned about the risk of serious side } \\
\text { effects (even with a very low probability) } \\
\text { than mild to moderate side effects (at } \\
\text { a much higher probability). Older } \\
\text { respondents were more willing than } \\
\text { younger respondents to accept an increased } \\
\text { risk of experiencing serious side effects for } \\
\text { an improvement in the symptoms of } \\
\text { osteoarthritis. The use of conjoint analysis } \\
\text { to assess patient preferences provides } \\
\text { a useful insight to the likely attitudes of } \\
\text { patients to novel treatments for } \\
\text { osteoarthritis. }\end{array}$ \\
\hline
\end{tabular}

\section{Treatment Preferences}

The review included studies investigating pharmaceutical, non-pharmaceutical, and surgical treatment for OA (see Table 1).

\section{NSAID and Other Medication Treatment}

The majority of studies investigated the side effects and other features of nonsteroidal anti-inflammatory drugs (NSAIDs) and other medications such as diseasemodifying drugs and supplements (glucosamine) on

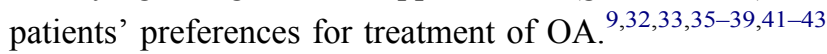

The relative importance of the risks of side effects; both rare and common were rated more important than the benefits associated with the treatment, time to benefit, out-of-pocket monthly cost, route of administration, and the product label. ${ }^{36-38}$ One study found that relatively the most important attribute was the route of administration (cream, pills, injections into the knee and exercise) (relative importance of 24\%), followed by the risk of dyspepsia and risk of bleeding ulcer, with the least important being decrease in pain and improved strength (relative importance of approximately $14 \%) .{ }^{42}$ Similarly, a study investigating the long-term evaluation of glucosamine sulphate, found that relatively the most important attributes were the side effects of high blood pressure, heart/liver/kidney problems followed by cost. ${ }^{33}$ The authors concluded that in their study, preferences to continue with OA treatments were influenced by side effects first and foremost and treatment efficacy did not significantly influence patient choice. ${ }^{33}$ Again, a study ${ }^{31}$ investigating 8 medication attributes, found that relatively the risks of side effects were the most important (combined their relative importance accounted for $66 \%$ of the treatment decision) and effectiveness of the medication only accounted for $8 \%$ of the treatment decision.

\section{Exercise Treatment}

One study examined patients' preferences for exercise in the context of other available treatment options (excluding surgery). ${ }^{42}$ The authors found that patients prefer exercise over pharmacological treatment for; risk of dyspepsia and bleeding ulcer combined accounted for the relative importance of $41.3 \%$ compared to $28.9 \%$ relative importance for both decrease pain and improve strength attributes. ${ }^{42}$ Another study investigated individual preferences for physical activity attributes (with no comparison to other types 
Table 2 Sampling for All Reviewed Studies

\begin{tabular}{|c|c|c|c|c|c|}
\hline Study & Country & $\begin{array}{l}\text { Sample } \\
\text { Size }\end{array}$ & $\mathbf{R} \mathbf{R}$ & Sampling Method & Inclusion Criteria \\
\hline $\begin{array}{l}\text { Al-Omari, } \\
(2017)^{31}\end{array}$ & UK & II & $100 \%$ & $\begin{array}{l}\text { Participants were drawn from members of } \\
\text { a Research Users' Group (RUG). }\end{array}$ & $\begin{array}{l}\text { Had been diagnosed with OA and had } \\
\text { reported one or more of hip, knee, hand } \\
\text { and foot joint pain in the past } 12 \text { months. }\end{array}$ \\
\hline $\begin{array}{l}\text { Al-Omari et al } \\
(2015)^{34}\end{array}$ & UK & 11 & $100 \%$ & $\begin{array}{l}\text { Members of a research users' group } \\
\text { (RUG) in a research centre who have } \\
\text { osteoarthritis were contacted by } \\
\text { telephone and invited to attend one group } \\
\text { session. }\end{array}$ & $\begin{array}{l}\text { Participants who were representative of } \\
\text { potential users of the software for } \\
\text { discrete choice experiments and shared } \\
\text { decision-making regarding OA medication } \\
\text { in clinical practice. } \\
\text { All participants were diagnosed with } \\
\text { osteoarthritis and reported experiencing } \\
\text { one or more of hip, knee, hand, or foot } \\
\text { joint pain in the past } 12 \text { months. }\end{array}$ \\
\hline $\begin{array}{l}\text { Al-Omari et al } \\
(2017)^{9}\end{array}$ & UK & 11 & $100 \%$ & $\begin{array}{l}\text { Random selection from members of } \\
\text { a research users' group (RUG) in } \\
\text { a research centre. }\end{array}$ & $\begin{array}{l}\text { Not previously involved in design of } \\
\text { ACBA task. with osteoarthritis and } \\
\text { reporting one or more of hip, knee, hand, } \\
\text { and foot joint pain over the previous } 12 \\
\text { months. }\end{array}$ \\
\hline $\begin{array}{l}\text { Byrne et al } \\
(2006)^{23}\end{array}$ & USA & $\begin{array}{l}\text { Public: } 193 \\
\text { Patient: } \\
198\end{array}$ & $\begin{array}{l}\text { Public: } \\
25 \% \\
\text { Patient: } \\
28 \%\end{array}$ & $\begin{array}{l}\text { Public sample: Random-digit-dialing list of } \\
4000 \text { telephone numbers } \\
\text { Patient sample: list of I } 286 \text { patients from } \\
\text { Kelsey Seybold clinics. }\end{array}$ & $\begin{array}{l}\text { Public sample: Adults living in Houston, } \\
\text { age } 20 \text { or older } \\
\text { Patient sample: Patients treated for knee } \\
\text { osteoarthritis, age } 55 \text { to } 80 \text {. }\end{array}$ \\
\hline $\begin{array}{l}\text { Chang et al } \\
(2005)^{32}\end{array}$ & $\begin{array}{l}\text { Australia, } \\
\text { Canada, } \\
\text { the UK, } \\
\text { and the } \\
\text { USA }\end{array}$ & 3895 & $\begin{array}{l}7.6 \% \text { of } \\
\text { the total } \\
\text { invitation }\end{array}$ & $\begin{array}{l}\text { Distributed } 57,452 \text { invitations by email } \\
\text { using Harris Interactive. Harris Interactive } \\
\text { is a website for methods and tools of } \\
\text { market research (Harris Interactive, } \\
2010 \text { ). }\end{array}$ & $\begin{array}{l}\text { Osteoarthritis patients who provided } \\
\text { consistent ratings to the benchmark rating } \\
\text { scenarios. }\end{array}$ \\
\hline $\begin{array}{l}\text { Fraenkel et al } \\
(2004 \mathrm{~A})^{37}\end{array}$ & USA & 100 & $84 \%$ & $\begin{array}{l}\text { Patients were sent a letter describing the } \\
\text { study and then contacted by telephone I } \\
\text { week later. }\end{array}$ & $\begin{array}{l}\text { Osteoarthritis patients having pain in one } \\
\text { or both knees on most days of the month } \\
\text { and not having rheumatoid arthritis, gout, } \\
\text { pseudogout, or bilateral knee } \\
\text { replacements. }\end{array}$ \\
\hline $\begin{array}{l}\text { Fraenkel et al } \\
(2004 \mathrm{~B})^{38}\end{array}$ & USA & 100 & $84 \%$ & $\begin{array}{l}\text { Patients were sent a letter describing the } \\
\text { study and then contacted by telephone I } \\
\text { week later. }\end{array}$ & $\begin{array}{l}\text { Osteoarthritis patients having pain in one } \\
\text { or both knees on most days of the month } \\
\text { and not having rheumatoid arthritis, gout, } \\
\text { pseudogout, or bilateral knee } \\
\text { replacements. }\end{array}$ \\
\hline $\begin{array}{l}\text { Fraenkel et al } \\
(2004 \mathrm{C})^{36}\end{array}$ & USA & 100 & $84 \%$ & $\begin{array}{l}\text { Patients were sent a letter describing the } \\
\text { study and then contacted by telephone I } \\
\text { week later. }\end{array}$ & $\begin{array}{l}\text { Osteoarthritis patients having pain in one } \\
\text { or both knees on most days of the month } \\
\text { and not having rheumatoid arthritis, gout, } \\
\text { pseudogout, or bilateral knee } \\
\text { replacements. }\end{array}$ \\
\hline $\begin{array}{l}\text { Fraenkel and } \\
\text { Fried, }(2008)^{42}\end{array}$ & USA & 90 & $78.9 \%$ & $\begin{array}{l}\text { A research assistant recruited participants } \\
\text { by approaching patients waiting in the } \\
\text { primary care waiting room area. }\end{array}$ & $\begin{array}{l}\text { Patients over } 60 \text { years of age, reporting } \\
\text { pain in one or both knees on most days of } \\
\text { the month, able to read and understand } \\
\text { English, and able to perform a choice task. }\end{array}$ \\
\hline
\end{tabular}

(Continued) 
Table 2 (Continued).

\begin{tabular}{|c|c|c|c|c|c|}
\hline Study & Country & $\begin{array}{l}\text { Sample } \\
\text { Size }\end{array}$ & $\mathbf{R R}$ & Sampling Method & Inclusion Criteria \\
\hline $\begin{array}{l}\text { Fraenkel et al } \\
(2014)^{34}\end{array}$ & USA & 304 & $100 \%$ & Convenience sample & $\begin{array}{l}\text { Patients attending general medicine and } \\
\text { subspecialty outpatient clinics affiliated } \\
\text { with a large university medical centre. }\end{array}$ \\
\hline $\begin{array}{l}\text { Harris et al } \\
(2018)^{44}\end{array}$ & USA & 404 & 49.5 & $\begin{array}{l}\text { Respondents were recruited via e-mail } \\
\text { invitation from Harris Interactive's } \\
\text { (Rochester, New York, USA) online } \\
\text { chronic-illness, panel in the UK. }\end{array}$ & $\begin{array}{l}\text { Participating patients were required to } \\
\text { have a self-reported physician's diagnosis } \\
\text { of } O A \text { and to be a UK resident aged } 45 \\
\text { years or older. }\end{array}$ \\
\hline $\begin{array}{l}\text { Hauber et al } \\
(2013)^{39}\end{array}$ & UK & 289 & $98 \%$ & $\begin{array}{l}\text { Respondents were recruited via e-mail } \\
\text { invitation from Harris Interactive's } \\
\text { (Rochester, New York, USA) online } \\
\text { chronic-illness panel in the UK. }\end{array}$ & $\begin{array}{l}\text { Participating patients were required to } \\
\text { have a self-reported physician's diagnosis } \\
\text { of } O A \text { and to be a UK resident aged } 45 \\
\text { years or older. }\end{array}$ \\
\hline $\begin{array}{l}\text { Laba et al } \\
(2013)^{33}\end{array}$ & Australia & 188 & $37 \%$ & $\begin{array}{l}\text { A paper-based survey was given to all } \\
\text { LEGS (Long-term Evaluation of } \\
\text { Glucosamine Sulfate study - a two-year, } \\
\text { double-blind, placebo-controlled } \\
\text { randomised clinical trial) participants } \\
\text { attending their end-of-study visit by } \\
\text { a member of the LEGS research team; } \\
\text { surveys were mailed to participants who } \\
\text { had already completed end-of-study visits. }\end{array}$ & $\begin{array}{l}\text { All LEGS participants completing their } \\
\text { end-of-study visit were eligible to } \\
\text { participate. }\end{array}$ \\
\hline $\begin{array}{l}\text { Moorman et al } \\
(2017)^{41}\end{array}$ & USA & 323 & $81.8 \%$ & $\begin{array}{l}\text { An email invitation to the survey was sent } \\
\text { in June } 2016 \text { to a group of Internet } \\
\text { panelists in the United States. They were } \\
\text { recruited from Research Now, an online } \\
\text { sampling and data collection company that } \\
\text { provides a nationally representative panel } \\
\text { of consumers. }\end{array}$ & $\begin{array}{l}\text { Men and women aged } 25 \text { to } 80 \text { years; } \\
\text { Diagnosed with OA in the knee; } \\
\text { Experience pain in the knee of } \geq 4 \text { on a } 0 \\
\text { to } 10 \text { scale, where } 0 \text { means not at all } \\
\text { painful and } 10 \text { means extremely painful; } \\
\text { Experience knee pain at least once a week; } \\
\text { Previously failed nonsurgical treatments } \\
\text { for knee OA pain; Pass a security screen; } \\
\text { No previous surgical implant involving the } \\
\text { knee (ie TKA, UKA). }\end{array}$ \\
\hline $\begin{array}{l}\text { Pinto et al } \\
(2019)^{40}\end{array}$ & USA & 150 & 97.3 & $\begin{array}{l}\text { Participants were recruited at community } \\
\text { senior centers and resource fairs and from } \\
\text { general internal medicine clinics at } \\
\text { Northwestern Medicine, the Shirley Ryan } \\
\text { AbilityLab (formerly the Rehabilitation } \\
\text { Institute of Chicago) and via flyers posted } \\
\text { on the Northwestern University medical } \\
\text { campus, Chicago, USA. }\end{array}$ & $\begin{array}{l}\text { Participants self-reported knee pain, ache } \\
\text { or stiffness on most days of at least I } \\
\text { month during the last year, were at least } \\
45 \text { years old, expressed interest in } \\
\text { increasing or maintaining PA, and had no } \\
\text { prior history of knee replacement on the } \\
\text { side of complaint. Participants underwent } \\
\text { a standing, fixed-flexion knee X-ray to } \\
\text { identify presence of KOA. }\end{array}$ \\
\hline $\begin{array}{l}\text { Ratcliffe et al } \\
(2004)^{43}\end{array}$ & $\begin{array}{l}\text { Not } \\
\text { reported. } \\
\text { Appear to } \\
\text { be the UK }\end{array}$ & 412 & $\begin{array}{l}\text { Not } \\
\text { reported }\end{array}$ & $\begin{array}{l}\text { The general population sample of } \\
\text { respondents aged } 55 \text { years and over was } \\
\text { identified using a market research } \\
\text { database. The respondents answered } \\
\text { a recruitment questionnaire over the } \\
\text { phone. }\end{array}$ & $\begin{array}{l}\text { Patients living with osteoarthritis over } 55 \\
\text { years of age. }\end{array}$ \\
\hline
\end{tabular}


Table 3 The CA Methods' Characteristics for All Reviewed Studies

\begin{tabular}{|c|c|c|c|c|}
\hline Study & $\begin{array}{l}\text { CA } \\
\text { Method }\end{array}$ & $\begin{array}{l}\text { Attributes/ } \\
\text { Levels }\end{array}$ & Scenarios & Statistical Analysis \\
\hline Al-Omari, $(2017)^{31}$ & $\mathrm{ACBC}$ & $8 / 28$ & Not reported & Hierarchical Bayes \\
\hline $\begin{array}{l}\text { Al-Omari et al } \\
(2015)^{34}\end{array}$ & ACBC & $8 / 28$ & Not reported & Not reported \\
\hline $\begin{array}{l}\text { Al-Omari et al } \\
(2017)^{9}\end{array}$ & $\mathrm{ACBC}$ & $8 / 28$ & Variable & Monotone regression \\
\hline $\begin{array}{l}\text { Byrne et al } \\
(2006)^{23}\end{array}$ & $\mathrm{CBC}$ & $6 / 17$ & $\begin{array}{l}36 \text { paired choices divided into } 6 \text { sets of } 6 \\
\text { paired scenarios and each participant was } \\
\text { randomly assigned to one of the } 6 \text { sets. }\end{array}$ & Logistic regression analysis \\
\hline $\begin{array}{l}\text { Chang et al } \\
(2005)^{32}\end{array}$ & CVA & $6 / 31$ & $\begin{array}{l}25 \text { OA health state-side effect scenarios } \\
\text { related to NSAIDs }\end{array}$ & Multivariable regression analysis \\
\hline $\begin{array}{l}\text { Fraenkel et al } \\
(2004 \mathrm{~A})^{37}\end{array}$ & $A C A$ & $7 / 27$ & Not reported & Least squares regression analysis \\
\hline $\begin{array}{l}\text { Fraenkel et al } \\
(2004 B)^{38}\end{array}$ & $\mathrm{ACA}$ & $7 / 27$ & Not reported & Least squares regression analysis \\
\hline $\begin{array}{l}\text { Fraenkel et al } \\
(2004 C)^{36}\end{array}$ & $\mathrm{ACA}$ & $7 / 27$ & Not reported & Least squares regression analysis \\
\hline $\begin{array}{l}\text { Fraenkel and Fried, } \\
(2008)^{42}\end{array}$ & $\mathrm{ACA}$ & $5 / 13$ & Not reported & Least squares regression analysis \\
\hline $\begin{array}{l}\text { Fraenkel et al } \\
(2014)^{35}\end{array}$ & $\mathrm{CBC}$ & $4 / 12$ & 12 & $\begin{array}{l}\text { Hierarchical Bayes (HB) modelling. Subsequently } \\
\text { performed Latent Class analysis to examine } \\
\text { whether preferences clustered by specific } \\
\text { segments. }\end{array}$ \\
\hline $\begin{array}{l}\text { Harris et al } \\
(2018)^{44}\end{array}$ & DCE & $5 / 12$ & 72 & $\begin{array}{l}\text { Individual pooled aggregate logit (Empirical Bayes } \\
\text { \& MLE) }\end{array}$ \\
\hline $\begin{array}{l}\text { Hauber et al } \\
(2013)^{39}\end{array}$ & DCE & $6 / 24$ & 30 , split across 3 questionnaires & $\begin{array}{l}\text { Random parameters logit model. All analyses } \\
\text { were conducted using NLOGIT 4.0. }\end{array}$ \\
\hline Laba et al $(2013)^{33}$ & DCE & $7 / 20$ & 16 & $\begin{array}{l}\text { For the choice data, a panel mixed multinomial } \\
\text { (random parameters) logit (MMNL) model was } \\
\text { used to investigate changes in utility (U) (ie } \\
\text { preference to continue taking a medication) } \\
\text { when the level of a factor was changed using } \\
\text { NLOGIT Version 4.0. }\end{array}$ \\
\hline $\begin{array}{l}\text { Moorman et al } \\
(2017)^{41}\end{array}$ & $\mathrm{CBC}$ & $9 / 29$ & 12 & $\begin{array}{l}\text { A hierarchical Bayesian multinomial logit model } \\
\text { was used to generate utilities that accounted for } \\
\text { individual preferences. }\end{array}$ \\
\hline Pinto et al $(2019)^{40}$ & $A C A$ & $6 / 18$ & On average 35 & $\begin{array}{l}\text { The PAPRIKA method was used to estimate } \\
\text { 'Part-worth utilities' (weights) representing the } \\
\text { relative importance of the attributes. }\end{array}$ \\
\hline $\begin{array}{l}\text { Ratcliffe et al } \\
(2004)^{43}\end{array}$ & DCE & $5 / 15$ & $\begin{array}{l}16 \text { paired choices divided into } 3 \text { sets of } 8 \\
\text { paired scenarios and each participant was } \\
\text { randomly assigned to one of the } 3 \text { sets. }\end{array}$ & Random effects probit regression model \\
\hline
\end{tabular}


of OA treatment).$^{40}$ This study found that "health benefits" (26\%) and "enjoyment" (24\%) attributes were considered by patients to be relatively the most important.

\section{Surgical Treatment}

Three studies investigated patients' preferences for surgical treatment of OA. One study investigated the relative preferences for 9 different surgical related procedure attributes and simulated how patients may have responded to real-world knee OA procedures based on their preferences. ${ }^{41}$ They found that patient preferences for surgical interventions were influenced by "the amount of cutting and removal of existing bone required" (relative importance of $18.7 \%$ ), followed by "chance of additional surgery" (relative importance of 14.1), "amount of pain relief" (relative importance of 12.7\%), with the least important attributes being "limits or complicates any future treatment need on the knee" and" length of hospital stay" with a relative importance of $7.3 \%$ each. ${ }^{41}$

Similarly, in the study comparing patient preferences for surgery for patients with a hand OA diagnosis, ${ }^{44}$ the authors found that "the need for future surgery" (relative importance $=19 \%$ ) and "recovery time" (relative importance $=3 \%$ ) were the least important factors influencing surgical preferences, while "joint stiffness" (relative importance $=32 \%$ ) and "grip strength" (relative importance $=29 \%$ ) were the most important. This supports the results from the earlier study that explored preferences for surgery versus medical treatment of knee $\mathrm{OA}^{23}{ }^{23}$ which found that the severity of OA symptoms, directly and indirectly, influenced the patients' choice of OA treatment, even in the presence of cultural differences in attitudes towards particular treatments.

\section{Discussion}

To the best of our knowledge, this is the first review to investigate and summarise the use of CA techniques to value patients' preferences for OA treatment. In addition, the search strategy was comprehensive, including the search of many databases, contacting authors and experts in the field, and searching the reference lists of published studies.

One of the limitations of this review is the lack of a validated quality assessment tool for CA studies. The use of the ISPOR checklist to score studies may be subjective to the examiner's opinion. We tried to assess the methodological quality of these studies using the ISPOR Conjoint Analysis Experimental Design Good Research
Practices Checklist. We were unable to make an objective decision regarding the minimum acceptable evidence required to award the scores. For example, question 2 "was the choice of attributes and levels supported by evidence?" we were unable to determine the quality and quantity of evidence required. This caused lengthy subjective disputes between the reviewers. Furthermore, the total scores for the studies indicated that CA studies published post the publication of the ISPOR checklist scored higher than those published pre-2011. This would be expected as most of these studies referenced ISPOR in their papers, meaning that we are assessing their quality against the same or similar criteria they used to design their studies, which was not available for studies published before 2011 . It is not clear if this improvement in the scores is correlated with the publication of the ISPOR checklist or is simply reflecting an improvement in reporting. We agree with Webb and colleagues that the ISPOR checklist should not be used as a quality assessment tool for conjoint studies in its current format, as it was not originally developed for this purpose. ${ }^{45}$

The studies have a high degree of heterogeneity in study design, study population, and treatment choice. The included papers incorporated studies using both rating/ ranking and choice-based methods to investigate different options of treatment for OA (exercise, medication, and surgery) in the UK, Australia, Canada, and the USA. All included studies had homogeneous samples in terms of suffering from OA. Thus, the studies sample may represent the OA population. However, the healthcare systems differ between the countries within which the studies were conducted; therefore, the generalisability of the results could be limited.

Variations in the sample sizes between included studies ( $\mathrm{n}=11$ to 3895$)$ may indicate that there is still no consensus on the appropriate or agreed sample size calculation method for CA studies, as it depends on many factors such as the number of questions and scenarios in the conjoint task. It has been suggested that the sample size for a CA study should be at least 300 in one sample group. ${ }^{46}$ However, the traditional calculations for sample size determination cannot readily be applied to $\mathrm{CA}^{43}$ and are rarely applied for practical reasons. ${ }^{47}$ Furthermore, it has been argued that collecting more data from each respondent by designing high-quality conjoint tasks may reduce sampling and measurement error. ${ }^{46}$ Using similar CA methods to those in the review ${ }^{36-38,42}$ in a study of patient preferences for acute pain treatment researchers attempted to reduce 
the limitation of a small sample (50 participants) by interviewing their respondents 4 times at 4 different stages of pain treatment. ${ }^{48}$ Limitations around sample size in CA studies may be overcome in the design of the conjoint task and data collection.

The variation in the RR ( $7.6 \%$ to $100 \%)$ in the studies is potentially a reflection of the robustness of the methods of recruitment and methods of data collection. The included studies used a variety of methods of data collection. Methods reporting face-to-face interviewing or questionnaires targeted a specific population of interest tended to have higher response rates. Studies using telephone interviewing or emails, predominantly in a general population, had a lower response rate. These studies with low RR recognised the limitations of using an untargeted strategy and suggested response rates could be improved in future research by pre-screening participants in order to target the full survey to those who report a diagnosis or other study characteristic of interest. ${ }^{32}$

All included studies recognised the value in utilising CA method to investigate patients' preferences for OA treatment, but there was no consensus on which CA approach is the most appropriate. Both rating/ranking and choice-based methods were used to examine patients' preferences for the treatment of OA. Recent academic and practical research applications have tended to favour choice-based approaches as opposed to rating/ranking. ${ }^{49}$ However, the rating/ranking approach has also been used and recommended by many researchers to study patients' preferences for OA treatment ${ }^{36-38,42}$ as well as treatment preferences in rheumatoid arthritis (RA), ${ }^{50}$ chronic pain, ${ }^{51}$ and abdominal surgery ${ }^{48}$ because it allows the inclusion of a large number of attributes and levels, which reflect the outcomes/concerns of patients with OA. The main advantage of ACA is that it is adaptive and therefore allows a large number of characteristics to be evaluated without resulting in information overload or respondent fatigue, and minimises interviewer, product, and brand bias. Nevertheless, there are still practical limitations associated with ACA, with researchers reporting that not all treatment characteristics could be included in an ACA task. ${ }^{36-38}$

In this review, studies that used the choice-based approach reported that the use of the discrete choice method allowed them to identify attributes significantly influencing patients' preferences for OA treatment. ${ }^{43}$ Furthermore, a very low number of inconsistent responses were found, and participants reported that the questions were easy or very easy to answer. ${ }^{23}$ Those studies that used $\mathrm{ACBC}^{9,31,34}$ argued that the approach can capture more individual-level data and precise estimates than through a traditional $\mathrm{CBC}$ approach and that it can yield similar group-level standard errors using up to $38 \%$ fewer participants. ${ }^{39,40}$ Furthermore, it has been reported that the ACBC method is more user friendly and engaging than alternative CA methods ${ }^{31,34,52,53}$ and it can be used to elicit individual patients' preferences. $^{9}$

Overwhelmingly the results of the studies in this review indicated that patient preferences for OA medications were driven by the desire to avoid both common and rare side effects, especially those with more serious drugrelated toxic effects and that the effectiveness of the OA medication had very little impact on patients' preferences. However, where investigated, studies suggested that preferences for side effects were affected by patient characteristics such as age and symptoms severity. Older respondents were more willing than younger respondents to trade-off an increased risk in the side effects ${ }^{36-38,43}$ for an improvement in the symptoms of OA. The side effects associated with NSAIDs had a greater negative influence on the preferences of patients with milder OA than those in more severe OA states. ${ }^{32}$ Even when exercise was compared to OA medications, patients were still more concerned about the side effects of the treatment than the benefits. ${ }^{42}$ However, patients with more knee pain were more reluctant to choose exercise.

Patients generally attached greater importance to reducing or eliminating adverse events than reducing pain, but one study investigated the level of treatment-related risks patients were willing to accept in exchange for various improvements in pain. ${ }^{39}$ The investigators found that participants" "risk tolerance" varied according to their pain level at baseline and type of symptom relief - participants were willing to accept greater risks for improvements in ambulatory pain than in resting pain. ${ }^{39}$ Similarly, a study of treatment options for disease-modifying drugs found that sub-groups of participants were willing to trade-off the risks of side-effects for improvements in a benefit. ${ }^{35} \mathrm{In}$ relation to surgical treatment for OA, it was reported that younger patients and those who reported the highest pain thresholds, and the greatest functional limitations were more likely to opt for surgical intervention. ${ }^{41}$ Furthermore, the severity of the patients underlying symptoms proved to be the main driver influencing their preferences for surgery. ${ }^{44}$

Where the severity of OA symptoms was measured alongside the conjoint task, all included studies suggested 
that the severity of symptoms influenced the patients' preference of treatment, and consequently the relative importance of treatment characteristics. However, it is not clear whether these differences are a result of symptom severity or artefacts of the CA methods, attributes used, or treatments being assessed.

\section{Conclusion}

The severity of OA symptoms and the side effects of treatment have a significant influence on patients' preferences for OA treatment. Both rating/ranking and choice-based CA methods are recommended in investigating patients' preferences for OA treatment, but there is no consensus on which CA approach is the most appropriate.

\section{Abbreviations}

ACA, Adaptive Conjoint Analysis; ACBC, Adaptive Choice-Based Conjoint; BWS, Best-Worst Scaling; CBC, Choice-Based Conjoint; CA, Conjoint Analysis; CVA, Conjoint Value Analysis; DCEs, Discrete Choice Experiments; HB, Hierarchical Bayesian; ISPOR, International Society of Pharmacoeconomics and Outcomes Research; MeSH, Medical Subject Headings; NHS, National Health Service; NSAIDs, Nonsteroidal Anti-Inflammatory Drugs; OA, Osteoarthritis; RR, Response Rates; RA, Rheumatoid Arthritis; UK, United Kingdom; USA, United States of America; WTP, Willingness to Pay.

\section{Data Sharing Statement}

The datasets used and/or analysed during the current study are available from the corresponding author on reasonable request.

\section{Author Contributions}

All authors made substantial contributions to conception and design, acquisition of data, or analysis and interpretation of data; took part in drafting the article or revising it critically for important intellectual content; agreed to submit to the current journal; gave final approval of the version to be published; and agree to be accountable for all aspects of the work.

\section{Disclosure}

The authors report no conflicts of interest in this work.

\section{References}

1. Neogi T. The epidemiology and impact of pain in osteoarthritis. Osteoarthr Cartil. 2013;21(9):1145-1153. doi:10.1016/j.joca.2013. 03.018

2. Al-Omari B. Osteoarthritis and management. OPROJ. 2019;5(5). doi:10.31031/OPROJ.2019.05.000622

3. W H O. Chronic rheumatic conditions. Chronic diseases and health promotion. Available from: https://www.who.int/chp/topics/rheu matic/en/. Accessed January 8, 2021.

4. Cooper C, Adachi JD, Bardin T, et al. How to define responders in osteoarthritis. Curr Med Res Opin. 2013;29(6):719-729. doi:10.1185/ 03007995.2013.792793

5. Nelson AE, Allen KD, Golightly YM, Goode AP, Jordan JM. A systematic review of recommendations and guidelines for the management of osteoarthritis: the chronic osteoarthritis management initiative of the U.S. bone and joint initiative. Semin Arthritis Rheum. 2014;43(6):701-712. doi:10.1016/j.semarthrit.2013.11.012

6. Overview | osteoarthritis: care and management | guidance | NICE. Available from: https://www.nice.org.uk/guidance/cg177. Accessed November 7, 2020.

7. Al-Omari B, Hill B. Nursing people with osteoarthritis. Br J Nurs. 2020;29(18):1060-1063. doi:10.12968/bjon.2020.29.18.1060

8. Hiligsmann M, Pinto D, Dennison E, et al. Patients' preferences for osteoarthritis treatment: the value of stated-preference studies. Aging Clin Exp Res. 2019;31(1):1-3. doi:10.1007/s40520-018-1098-3

9. Al-Omari B, Sim J, Croft P, Frisher M. Generating individual patient preferences for the treatment of osteoarthritis using Adaptive Choice-Based Conjoint (ACBC) analysis. Rheumatol Ther. 2017;4 (1):167-182. doi:10.1007/s40744-017-0056-4

10. Rivero-Santana A, Perestelo-Perez L, Perez-Ramos J, GonzalezLorenzo M, Serrano-Aguilar P. Treatment preferences in patients with knee or hip osteoarthritis: an overview. In: Chen Q, editor. Osteoarthritis - Diagnosis, Treatment and Surgery. InTech;2012. doi: $10.5772 / 26343$

11. Harrison M, Milbers K, Hudson M, Bansback N. Do patients and health care providers have discordant preferences about which aspects of treatments matter most? Evidence from a systematic review of discrete choice experiments. BMJ Open. 2017;7(5): e014719. doi:10.1136/bmjopen-2016-014719

12. Health and social care act; 2012. Available from: https://www.legislation. gov.uk/ukpga/2012/7/contents/enacted. Accessed November 7, 2020.

13. Cunningham $\mathrm{CE}$, Deal $\mathrm{K}$, Rimas $\mathrm{H}$, et al. Using conjoint analysis to model the preferences of different patient segments for attributes of patient-centered care. Patient. 2008;1(4):317-330. doi:10.2165/ 1312067-200801040-00013

14. Epstein RM, Franks P, Fiscella K, et al. Measuring patient-centered communication in patient-physician consultations: theoretical and practical issues. Soc Sci Med. 2005;61(7):1516-1528. doi:10.1016/j. socscimed.2005.02.001

15. Shields GE, Brown L, Wells A, Capobianco L, Vass C. Utilising patient and public involvement in stated preference research in health: learning from the existing literature and a case study. Patient. 2020. doi:10.1007/s40271-020-00439-2

16. Louviere JJ, Lancsar E. Choice experiments in health: the good, the bad, the ugly and toward a brighter future. Health Econ Policy Law. 2009;4(4):527-546. doi:10.1017/S1744133109990193

17. Brown L, Lee T-H, De Allegri M, Rao K, Bridges JF. Applying stated-preference methods to improve health systems in sub-Saharan Africa: a systematic review. Expert Rev Pharmacoecon Outcomes Res. 2017;17(5):441-458. doi:10.1080/14737167.2017.13 75854

18. Clark MD, Determann D, Petrou S, Moro D, de Bekker-grob EW. Discrete choice experiments in health economics: a review of the literature. Pharmacoeconomics. 2014;32(9):883-902. doi:10.1007/ s40273-014-0170-x 
19. Al-Omari B. The shared decision for osteoarthritis treatments. OPROJ. 2019;5(5). doi:10.31031/OPROJ.2019.05.000625

20. Ryan M, Gerard K. Using discrete choice experiments to value health care programmes: current practice and future research reflections. Appl Health Econ Health Policy. 2003;2(1):55-64.

21. Rao VR. Conjoint Analysis. In: Sheth J, Malhotra N, editors. Wiley International Encyclopedia of Marketing. Chichester, UK: John Wiley \& Sons, Ltd; 2010. doi:10.1002/9781444316568.wiem02019.

22. Cheung KL, Wijnen BFM, Hollin IL, et al. Using best-worst scaling to investigate preferences in health care. Pharmacoeconomics. 2016;34(12):1195-1209. doi:10.1007/s40273-016-0429-5

23. Byrne MM, Souchek J, Richardson M, Suarez-Almazor M. Racial/ ethnic differences in preferences for total knee replacement surgery. $J$ Clin Epidemiol. 2006;59(10):1078-1086. doi:10.1016/j.jclinepi.20 06.01 .010

24. Slothuus Skjoldborg U, Gyrd-Hansen D. Conjoint analysis. The cost variable: an Achilles' heel? Health Econ. 2003;12(6):479-491. doi:10.1002/hec.742

25. Marshall D, Bridges JFP, Hauber B, et al. Conjoint analysis applications in health - how are studies being designed and reported?: an update on current practice in the published literature between 2005 and 2008. Patient. 2010;3(4):249-256. doi:10.2165/11539650000000000-00000

26. Bridges JFP, Hauber AB, Marshall D, et al. Conjoint analysis applications in health-a checklist: a report of the ISPOR good research practices for conjoint analysis task force. Value Health. 2011;14 (4):403-413. doi:10.1016/j.jval.2010.11.013

27. Ryan M, Scott DA, Reeves C, et al. Eliciting public preferences for healthcare: a systematic review of techniques. Health Technol Assess. 2001;5(5):1-186. doi:10.3310/hta5050

28. Reed Johnson F, Lancsar E, Marshall D, et al. Constructing experimental designs for discrete-choice experiments: report of the ISPOR conjoint analysis experimental design good research practices task force. Value Health. 2013;16(1):3-13. doi:10.1016/j.jval.2012.08. 2223

29. Soekhai V, de Bekker-grob EW, Ellis AR, Vass CM. Discrete choice experiments in health economics: past, present and future. Pharmacoeconomics. 2019;37(2):201-226. doi:10.1007/s40273-0180734-2

30. Soekhai V, Whichello C, Levitan B, et al. Methods for exploring and eliciting patient preferences in the medical product lifecycle: a literature review. Drug Discov Today. 2019;24(7):1324-1331. doi:10.1016/j.drudis.2019.05.001

31. Al-Omari B. Patient preferences for the pharmacological treatment of osteoarthritis using adaptive choice-based conjoint (ACBC) analysis: a pilot study. Eur J Pers Cent Healthc. 2017;5(2):220. doi:10.5750/ ejpch.v5i2.1293

32. Chang J, Kauf TL, Mahajan S, et al. Impact of disease severity and gastrointestinal side effects on the health state preferences of patients with osteoarthritis. Arthritis Rheum. 2005;52(8):2366-2375. doi:10. 1002/art.21227

33. Laba T-L, Brien J, Fransen M, Jan S. Patient preferences for adherence to treatment for osteoarthritis: the MEdication Decisions in Osteoarthritis Study (MEDOS). BMC Musculoskelet Disord. 2013;14:160. doi:10.1186/1471-2474-14-160

34. Al-Omari B, Sim J, Croft P, Frisher M. Patient preferences for the pharmacological treatment of osteoarthritis: a feasibility study using adaptive choice-based conjoint analysis (ACBCA). Eur J Pers Cent Healthc. 2015;3(2):253. doi:10.5750/ejpch.v3i2.975

35. Fraenkel L, Suter L, Cunningham CE, Hawker G. Understanding preferences for disease-modifying drugs in osteoarthritis. Arthritis Care Res (Hoboken). 2014;66(8):1186-1192. doi:10.1002/acr.22280

36. Fraenkel L, Wittink DR, Concato J, Fried T. Are preferences for cyclooxygenase- 2 inhibitors influenced by the certainty effect? J Rheumatol. 2004;31(3):591-593.
37. Fraenkel L, Wittink DR, Concato J, Fried T. Informed choice and the widespread use of antiinflammatory drugs. Arthritis Rheum. 2004;51 (2):210-214. doi:10.1002/art.20247

38. Fraenkel L, Bogardus ST, Concato J, Wittink DR. Treatment options in knee osteoarthritis: the patient's perspective. Arch Intern Med. 2004;164(12):1299-1304. doi:10.1001/archinte.164.12.1299

39. Hauber AB, Arden NK, Mohamed AF, et al. A discrete-choice experiment of United Kingdom patients' willingness to risk adverse events for improved function and pain control in osteoarthritis. Osteoarthr Cartil. 2013;21(2):289-297. doi:10.1016/j.joca.2012.11. 007

40. Pinto D, Bockenholt U, Lee J, et al. Preferences for physical activity: a conjoint analysis involving people with chronic knee pain. Osteoarthr Cartil. 2019;27(2):240-247. doi:10.1016/j.joca.2018.10. 002

41. Moorman CT, Kirwan T, Share J, Vannabouathong C. Patient preferences regarding surgical interventions for knee osteoarthritis. Clin Med Insights Arthritis Musculoskelet Disord. 2017;10:117954 4117732039. doi:10.1177/1179544117732039

42. Fraenkel L, Fried T. If you want patients with knee Osteoarthritis (OA) to Exercise: tell them about NSAIDS. Patient. 2008;1 (1):21-26. doi:10.2165/01312067-200801010-00005

43. Ratcliffe J, Buxton M, McGarry T, Sheldon R, Chancellor J. Patients' preferences for characteristics associated with treatments for osteoarthritis. Rheumatology. 2004;43(3):337-345. doi:10.1093/rheumatology/keh038

44. Harris CA, Shauver MJ, Yuan F, Nasser J, Chung KC. Understanding patient preferences in proximal interphalangeal joint surgery for osteoarthritis: a conjoint analysis. J Hand Surg Am. 2018;43 (7):615-624.e4. doi:10.1016/j.jhsa.2018.03.001

45. Webb EJD, Meads D, Eskyte I, et al. A systematic review of discrete-choice experiments and conjoint analysis studies in people with multiple sclerosis. Patient. 2018;11(4):391-402. doi:10.1007/ s40271-017-0296-y

46. Orme BK. Getting Started with Conjoint Analysis: Strategies for Product Design and Pricing Research. 2nd ed. Research Publishers, LLC; 2009:228.

47. de Bekker-grob EW, Donkers B, Jonker MF, Stolk EA. Sample size requirements for discrete-choice experiments in healthcare: a practical guide. Patient. 2015;8(5):373-384. doi:10.1007/s40271015-0118-z

48. Gan TJ, Lubarsky DA, Flood EM, et al. Patient preferences for acute pain treatment. Br J Anaesth. 2004;92(5):681-688. doi:10.1093/bja/ aeh123

49. Orme BK Which conjoint method should i use? Sawtooth technical papers; 2013. Available from: https://sawtoothsoftware.com/ resources/technical-papers/which-conjoint-method-should-i-use. Accessed January 7, 2021.

50. Fraenkel L, Bogardus ST, Concato J, Felson DT, Wittink DR. Patient preferences for treatment of rheumatoid arthritis. Ann Rheum Dis. 2004;63(11):1372-1378. doi:10.1136/ard.2003.019422

51. Schmier JK, Palmer CS, Flood EM, Gourlay G. Utility assessments of opioid treatment for chronic pain. Pain Med. 2002;3(3):218-230. doi:10.1046/j.1526-4637.2002.02045.x

52. Al-Omari B, McMeekin P. Patients' preferences regarding osteoarthritis medications: an adaptive choice-based conjoint analysis study. Patient Prefer Adherence. 2020;14:2501-2515. doi:10.2147/PPA. S283922

53. Al-Omari B, Frisher M, Croft P, Sim J. FRI0567-PC Using adaptive choice based conjoint (ACBC) analysis to study patients' preferences regarding pharmaceutical treatment for osteoarthritis (OA). Ann Rheum Dis. 2013;72(Suppl 3):A567.2-A567. doi:10.1136/annrheumdis-2013-eular.1694

54. Moher D, Liberati A, Tetzlaff J, Altman DG. The PRISMA Group (2009). Preferred Reporting Items for Systematic Reviews and MetaAnalyses: The PRISMA Statement. PLoS Med. 2009;6(7):e1000097. 


\section{Publish your work in this journal}

Patient Preference and Adherence is an international, peer-reviewed, open access journal that focusing on the growing importance of patient preference and adherence throughout the therapeutic continuum. Patient satisfaction, acceptability, quality of life, compliance, persistence and their role in developing new therapeutic modalities and compounds to optimize clinical outcomes for existing disease

states are major areas of interest for the journal. This journal has been accepted for indexing on PubMed Central. The manuscript management system is completely online and includes a very quick and fair peer-review system, which is all easy to use. Visit http:// www.dovepress.com/testimonials.php to read real quotes from published authors. 